\title{
MIGRATION PROCESSES AND LEGAL ADJUSTMENT: CHECHEN MIGRANTS TO THE EU AND CIRCASSIAN MINORITY IN JORDAN
}

\author{
Dmytro Poble \\ Odessa I. I. Mechnikov National University, \\ Faculty of International Relations, Political Science and Sociology, \\ Department of International Relations \\ Dvoryanskaya str., 2, 65082, Odessa, Ukraine
}

The primary purpose of the article is to outline the European legal fundamentals, regulating migration processes, to review an unfortunate integration of Chechen migrants into European society at the threshold of a new millennium and an example of successful Circassian political and cultural integration in Jordan throughout two centuries, comparing two Caucasian ethnic groups forced to leave their homeland in different periods of the history.

Immigration is considered as a process by means of which individuals transfer into permanent residents or citizens of a new country. Deep in the history the process of immigration has been supposed to constitute a certain social, economic, and cultural benefit to states. Therefore migration processes in the Middle East and Northern Africa became a serious global challenge lately. In 2015 and 2016 the European Union (EU) faced an unprecedented influx of migrants and refugees. Europe wasn't prepared either morally or legally to confront this course of events. The European legal fundamentals are based primarily on the Treaty of Lisbon (as follow-up to the Treaty of Rome and Treaty of Maastricht) as constitutional component as well as they are based on the Schengen Agreement of 26 European countries and the Dublin Regulation as operational component. The Dublin III Regulation (Regulation No. 604/2013) is a EU law that defines which EU Member State takes the responsibility for the examination of any application for asylum, submitted by individuals looking for international protection due to the Geneva Convention and the EU Qualification Directive (2005/36/EC of the European Parliament and of the Council of 7 September 2005 on the recognition of professional qualifications), within the European Union. Beside Syrian refugees' crisis it has been previous unfortunate development of the Chechen minority trying to integrate within EU society after Chechen-Russian wars in Caucasus. Their integration was seriously hampered by certain traditions and peculiarities of Chechen self-consciousness i.e. the primacy of traditional law and the habits of living due to the "laws of fathers", and neither the state; ideas about the role of women, the rules of blood feud, collective responsibility, and the closeness of the Chechen community.

Incidentally, the history knows some successful examples of ethnic minorities' integration into new societies while fleeing from war conflicts and genocide threats. The Circassian ethnic group constitutes $1 \%$ of the Jordanian population only, but it occupies a certain influential political and cultural position. A brief historical background of the Caucasian refugees prior to their settlement in Transjordan indicates the approach by which the Circassians reached their status in Jordanian society and maintained it. The loyalty to the Hashemite monarchy was the key factor which helped to keep the Circassians at high political and social position of the Jordanian establishment. Throughout two centuries, the military attitude and agricultural experience of the Circassian minority have been transferred and replaced by their unique cultural heritage and memorable traditions, as well as successful activities in the humanitarian and political sectors. The latest public opinion polls of Jordanian Circassians indicate a significant decrease of their interest to be repatriated to the historical homeland and to reveal unpleasant reality of staying today in this part of Caucasus area.

Key words: migration processes, integration into society, genocide, loyalty to the monarchy, cultural heritage, public opinion polls, repatriation.

(c) D. Poble, 2019 
As usual, immigration is defined as " $<\ldots>$ a process through which individuals become permanent residents or citizens of a new country $\langle\ldots>$ The immigration experience is long and varied and has in many cases resulted in the development of multicultural societies" [1].

Nowadays the migration flow from the Middle East (ME) and Northern Africa became a serious global challenge to Europe, because the migration processes involves three continents thus enveloping Europe by its neighbors. People all over the world have always used to cross the borders searching for a better life and migrating from one place to another. But in the last decade the ME migrants try to reach European lands for different reasons and in different ways. The situation is too much complicated to find out the very reason of migration (civil wars, famine, social-economic factors, different religious attitudes and seasonal labor migration): the motives are intertwined. "In 2015 and 2016 the EU experienced an unprecedented influx of refugees and migrants. More than 1 million people arrived in the European Union, most of them fleeing from war and terror in Syria and other countries" [2].

It is also not easy to differentiate between legal and illegal migration. The statistics are not complete, as only a certain number of migrants officially register with the International Organization for Migration, the Office of the United Nations High Commissioner for Refugees and other relevant organizations. (See the table below) [3].

Dead and missing in 2019 (estimate) 283

\begin{tabular}{|c|c|c|}
\hline Previous years & Arrivals * & Dead and missing \\
\hline 2018 & 141,472 & 2,277 \\
\hline 2017 & 185,139 & 3,139 \\
\hline 2016 & 373,652 & 5,096 \\
\hline 2015 & $1,032,408$ & 3,771 \\
\hline 2014 & 225,455 & 3,538 \\
\hline
\end{tabular}

* Arrivals include sea arrivals to Italy, Cyprus and Malta and both sea and land arrivals to Greece and Spain

The European legal fundamentals are based primarily on the Treaty of Lisbon (as follow-up to the Treaty of Rome and Treaty of Maastricht) as constitutional component as well as they are based on the Schengen Agreement of 26 European countries and the Dublin Regulation as operational component. The Dublin III Regulation (Regulation No 604/2013) determines which EU-state should evaluate the asylum claims forwarded by the individuals who arrive in Europe. The document entered into force in January 2014 and it set down "the criteria and the mechanisms of determination of the Member State in charge of examining the request of international protection presented by a third-country national or by a stateless person in one of the European states" [4].

French and British models of integration policies have been known historically for a long period of time forming two mutually exclusive paradigms. "Built on elements of the ideology introduced during the French Revolution, French citizenship is perceived as refusing any form of distinction on ethno-racial lines in the public sphere... British policies have appeared to represent its antithesis with an approach based on the importance of minority groups and some recognition of multiculturalism as a social and political feature of British society" [5]. These conceptual models of immigrant integration, i.e. French assimilation and British multiculturalism, has found many supporters in European comparative research works, taking into consideration and explaining many national differences. Thus the concept may be a little problematic because it suffers from normative and theoretical misconceptions. Therefore the "models should not be considered as homogeneous and stable cultural entities but as complex structures of reference on the basis of which a multiplicity of conceptions of identity, equality, and inclusion are developed by a wide range of social agents in each national context" [6]. 
Вісник Львівського університету. Серія філос.-політолог. студії. 2019. Випуск 24

Beside Syrian refugees' crisis it has been previous unfortunate development of the Chechen minority trying to integrate within EU society after Chechen-Russian wars in Caucasus. Their integration was seriously hampered by certain traditions and peculiarities of Chechen self-consciousness i.e. the primacy of traditional law and the habits of living due to the "laws of fathers", and neither the state; ideas about the role of women, the rules of blood feud, collective responsibility, and the closeness of the Chechen community.

In 2018, a conflict between Chechen and Afghan refugees in East Cottbus caused the great resonance in Germany. As the Interior Minister of Brandenburg, Karl-Heinz Schroeter, said in an interview with DW, problems with the Chechens also arose in other cities. Chechens, who felt offended, are able even in Germany to mobilize large groups of their countrymen. The German minister is sure that some of the people from Chechnya do not want to integrate. Their goal is to live in Germany, but by their own laws. He also noted that there is some evidence of possible links between representatives of the Chechen community and organized crime. In particular, it concerns human trafficking and illegal migration [7].

European continent hasn't been the only asylum which has attracted Iraqi and Syrian migrants escaping from the depressing realities of war time and Islamic State combatants' crimes in their home countries. There has been a neighbor called the Hashemite Kingdom of Jordan i.e. a conjunct monarchy historically and geographically related to Iraq and Syria. According to the Statistical database of United Nations High Commissioner for Refugees (UNHCHR) during the period of 2006-2011 Jordan was receiving 450-500 thousands Iraqi refugees each year and it was receiving 585-648 thousands Syrian refugees in 2013-2016 (See the table below) [8].

Table with Data on Refugees

\begin{tabular}{|c|c|c|c|c|c|c|}
\hline $\begin{array}{l}\text { Country } \\
\text { or territory } \\
\text { of asylum or } \\
\text { residence }\end{array}$ & $\begin{array}{l}\text { Country } \\
\text { or territory } \\
\text { of origin }\end{array}$ & Year & Refugees ${ }^{*}$ & $\begin{array}{l}\text { Refugees } \\
\text { assisted by } \\
\text { UNHCR }\end{array}$ & $\begin{array}{l}\text { Total refugees } \\
\text { and people in } \\
\text { refugee-like } \\
\text { situations }\end{array}$ & $\begin{array}{l}\text { Total refugees } \\
\text { and people in } \\
\text { refugee-like } \\
\text { situations assisted } \\
\text { by UNHCR }\end{array}$ \\
\hline Jordan & Iraq & 2016 & 33,118 & 33,118 & 33,118 & 33,118 \\
\hline Jordan & Syria & 2016 & 648,836 & 648,836 & 648,836 & 648,836 \\
\hline Jordan & Iraq & 2015 & 33,256 & 33,256 & 33,256 & 33,256 \\
\hline Jordan & Syria & 2015 & 628,223 & 628,223 & 628,223 & 628,223 \\
\hline Jordan & Iraq & 2014 & 29,263 & 29,263 & 29,263 & 29,263 \\
\hline Jordan & Syria & 2014 & 623,112 & 623,112 & 623,112 & 623,112 \\
\hline Jordan & Iraq & 2013 & 55,509 & 20,286 & 55,509 & 20,286 \\
\hline Jordan & Syria & 2013 & 585,304 & 585,304 & 585,304 & 585,304 \\
\hline Jordan & Iraq & 2012 & 63,037 & 27,814 & 63,037 & 27,814 \\
\hline Jordan & Syria & 2012 & 238,798 & 118,908 & 238,798 & 118,908 \\
\hline Jordan & Iraq & 2011 & 450,000 & 32,197 & 450,000 & 32,197 \\
\hline Jordan & Syria & 2011 & 193 & 193 & 193 & 193 \\
\hline Jordan & Iraq & 2010 & 450,000 & 30,098 & 450,000 & 30,098 \\
\hline Jordan & Syria & 2010 & 198 & 198 & 198 & 198 \\
\hline Jordan & Iraq & 2009 & 450,000 & 46,600 & 450,000 & 46,600 \\
\hline Jordan & Syria & 2009 & 138 & 138 & 138 & 138 \\
\hline Jordan & Iraq & 2008 & 500,000 & 52,668 & 500,000 & 52,668 \\
\hline Jordan & Syria & 2008 & 44 & 44 & 44 & 44 \\
\hline Jordan & Iraq & 2007 & 500,000 & 51,023 & 500,000 & 51,023 \\
\hline Jordan & Syria & 2007 & 41 & 41 & 41 & 41 \\
\hline Jordan & Iraq & 2006 & 500,000 & & 500,000 & \\
\hline Jordan & Syria & 2006 & 42 & 42 & 42 & 42 \\
\hline
\end{tabular}


The dramatic inflow of refugees hasn't happened to modern Jordan for the first time. Amman, the capital city of Jordan today, knows another period of its historical record when it was resettled in 1878 by Circassians of the Shapsough tribe. The region of Amman, which was annexed by the Ottoman Empire in 1516, and wasn't considered as a political centre of Transjordan, started its resettlement in 1878, when hundreds of Circassian refugees found their asylum following the exodus from the Caucasus. Tens of thousands of Circassians were relocated coercively in 1872-1910, to Ottoman Syria (Transjordan) from their historical Circassia by Russian Empire following the dramatic events of the Russo-Circassian War.

This outflow of the North Caucasian migrants is associated with the movement of Muhajirism, the tragic departure of Abkhazians and Circassians, to a lesser extent - Chechens, Dagestanis and Ossetians from their historic homeland. The Russian historian Gordin from St. Petersburg called this outcome a psychological catastrophe, since the Caucasian highlanders have lost their internal ties with the "fertile homeland", and a stable system of social connections with their natural and cultural environment. In his monograph he characterized the Caucasian drama as one of the prolonged and bitter conflicts in Russian history. "The fierce war ..., lasted for sixty years in the 19th century, and which emerged at the end of the 20th century as a swollen underground stream, appreciably affected Russia's destiny" [9].

The history of the Mohajirism of the peoples of the North Caucasus in the Ottoman Empire is connected with the process of state territorial delimitation and the inclusion of the region into the Russian Empire in the last quarter of the 18th - first half of the 19th centuries. But the real conquest of a large part of the North Caucasus continued throughout the second half of the nineteenth century. Accession was carried out less frequently through treaties, more often through military action. The entry in 1801 of the East Georgian Kartli-Kakheti kingdom into Russia led to the intensification of military operations of the Russian army in the North Caucasus.

The long struggle of the Russian Empire for the conquest of the Caucasus led to the fact that a significant part of the indigenous population left their homeland and moved to the Ottoman Empire. The once numerous peoples of Circassian (Adyghe) origin (700-750 thousand people) were in the minority and, as Muslim people indigenous to Caucasia, had long been persecuted by Russian Empire. "The last remnants of Circassians' resistance against the Russians ended around today's Black Sea port city of Sochi on May 21, 1864" [10].

It is worthy to note that "before the onset of Russian aggression, the Circassian Nation used to be the largest in the whole of the Caucasus $\langle\ldots\rangle$ it is possible to calculate the number of Circassians that would have been living in the Caucasus today, had the Russians not embarked on their devastating war. This comes up to 10 million $<\ldots>$ If this number is compared to that of Northwest Caucasians actually living in the Caucasus at present, which is about a million, then one can begin to appreciate the full extent of the disaster that befell them" [11].

After that time, the Circassians have had a dominant role in the development of Jordan, following high ranked positions within the Jordanian government, Armed Forces and Police. Circassians were granted the position of personal royal guard by King Abdullah the $1^{\text {st }}$ in 1921 . Since that time, the Circassians have been on service as the royal guard to all the consequent Jordanian Kings: King Abdullah the $1^{\text {st }}$, King Talal the $1^{\text {st }}$, King Hussein the $1^{\text {st }}$ and King Abdullah the $2^{\text {nd }}$. In the following period (1932) the Circassian Charity Association was established and it turned to be the second oldest charity group in Jordan. In 1944 Circassian sports club Al-Ahli was founded. In 1950 club New Generation (Al-Jeel Al-Jadeed in Arabic) was opened with the aim to preserve the Culture of Circassia. The Circassian Culture Academy was founded in 2009, aiming to conserve the Circassian language, which comprises both Adyghe and Kabardian languages (sometimes they are considered to be dialects of Circassian). It was 1994, when the Al-Ahli 
Club organized a Circassian Folkloric Dance troupe. There is another Circassian Folkloric Dance troupe named the Highlanders which established at the Circassian Culture Academy.

Jordanian Parliament (called Majlis al-Umma in Arabic) was established due to the 1952 Constitution and consists of two chambers: the Senate (Mejlis Al-Aaian) and the House of Representatives (Mejlis An-Nuwab). The Senate counts 65 members, each senator is directly appointed by the King, meanwhile the House of Representatives consists of 130 elected members; meanwhile nine of the total seats are reserved for Christians, three of them are designated for Circassian and Chechen minorities and fifteen are for women. Jordan's political arena turned to be some kind of preserve to the Circassian minority and demonstrated a prestigious history of participation unfolded over subsequent years. "This has included the first prime minister in 1923, and first female lawmaker in 1993. To these may be added senior civil positions such as mayors, and deputies, as well as the top brass of the army, air force, and intelligence community" [12].

The renewal of young Circassians and their participation in the social-economic events and the development of Jordan has brought them to rapid assimilation. Their attendance to the higher education has changed the relevance of stereotypical career as a landlord, army officer and government employee to new professions related to civil engineering technologies, public health, private enterprising and industries. The old traditional elite of Circassian minority has been overtaken by a new highly motivated generation. Unfortunately "The language is irrevocably lost and traditions have been largely discarded. The new generation must be given an identity that is in harmony with the past and in line with the present" [13].

Large majority within the Circassian community of Jordan consider themselves as Circassians who keep their peculiarities and values which bring them closer to their historical homeland. Anyway they identify their future first of all with Jordanian monarchy regarding the Hashemite kingdom "as the best place for life and career" Even those who in principle would like to return to the Caucasus are frightened away by instability there" [14]. They still keep in mind the Caucasus as an object of nostalgia and a place for short visits but neither a permanent place to stay.

Historically, the immigration experience is long and varied and has in many cases resulted in the development of multicultural societies. Two discrete cases of North Caucasian migrants Chechen and Circassian minorities - indicate the examples of unfortunate and lucky integration of refugees into European and Jordanian public communities within the time gap of 200 years. The Circassians have been really successful in their new Jordanian homeland. They consider themselves as full-fledged members of the society and they are actively engaged in the Hashemite Kingdom's life despite being cognizant of Circassian ethnic and cultural identity.

\section{Список використаної літератури}

1. Sarah Parry, 'Immigration'. Encyclopedia Britannica (21 May 2013). URL: https://www. britannica.com/topic/immigration (accessed 18 February 2019).

2. Corporate author(s), 'The EU and the migration crisis'. Directorate-General for Communication (European Commission) (11 October 2017). URL: publications.europa.eu/ webpub/com/factsheets/migration-crisis/en (accessed 18 February 2019).

3. UNCHR the UN Refugee Agency, 'Mediterranean situation'. Operational Portal/Refugee Situations (26 March 2019). URL: https://data2.unhcr.org/en/situations/mediterranean (accessed 26 March 2019).

4. Annapaola Ammirati. What is the Dublin Regulation. Open Migration (8 December 2015). URL: https:/openmigration.org/en/analyses/what-is-the-dublin-regulation (accessed 26 March 2019).

5. Christophe Bertossi. French and British models of integration. ESRC Centre on Migration, Policy and Society Working Paper. 2007. No. 46. Pp. 3-4 
6. Christophe Bertossi. National Models of Integration in Europe: A Comparative and Critical Analysis. Research Gate (November 2011). URL: https://www.researchgate.net/ publication/238043202_National_Models_of_Integration_in_Europe_A_Comparative_ and_Critical_Analysis (accessed $2 \overline{6}$ March $201 \overline{9}$ ).

7. Esipov V. Interview DW with Interior minister of Brandenburg, Karl Heinz Schroeter. $D W /$ Russian edition (27 February 2019). URL: https://p.dw.com/p/3DqYm (accessed 11 March 2019).

8. UNHCR Statistical Database. 'Table with Data on Refugees', United Nations High Commissioner for Refugees (2 November 2017). URL: http://data.un.org/Data. aspx?d=UNHCR\&f=indID\%3AType-Ref (accessed 28 February 2019).

9. Gordyn Ya. Caucasian Atlántida. 300 years of war. You-books.com. The biggest library (2014). URL: http://www.you-books.com/book/Ya-Gordin/Kavkazskaya-Atlantida-300-letvojny (accessed 29 February 2019).

10. Murat Sofuoglu. The Circassian exile: 9 facts about the tragedy Peele. TRT World, News/ Europe (14 May 2016). URL: https://www.trtworld.com/europe/the-circassian-exile-9interesting-facts-106062 (accessed at 26 March 2019).

11. Amjad Jaimoukha. The Circassians in Jordan. Circassian World (2019). URL: http:// www.circassianworld.com/new/middle-east/1249-the-circassians-in-jordan.html. (accessed 31 March 2019).

12. Mark Szawlowski. Circassians in Jordan. The Business Year/ Focus: Caucasian Diaspora in Middle East (26 September 2018). URL: https:/www.thebusinessyear.com/the-circassiansand-their-role-in-jordan/focus (accessed 31 March 2019).

13. Amjad Jaimoukha. The Circassians in Jordan. Circassian World (2019). URL: http:// www.circassianworld.com/new/middle-east/1249-the-circassians-in-jordan.html (accessed 31 March 2019).

14. Ganich A. Circassian diaspora in Jordan (self-identification, ideas about historical homeland and impact on North Caucasian developments). CA\&C Press AB Publishing House (Sweden/ Journal 2003). URL: https://www.ca-c.org/journal/2003/journal_eng/cac-01/03.ganeng.shtm (accessed 10 April 2019).

\title{
МІГРАЦІЙНІ ПРОЦЕСИ ТА АДАПТАЦІЯ У ПРАВОВОМУ СЕРЕДОВИЩІ: ЧЕЧЕНСЫКІ ЕМІГРАНТИ В ЄС ТА ЧЕРКАСЬКА ЕТНІЧНА МЕНШИНА У ЙОРДАНІЇ
}

\author{
Дмитро Побле \\ Одеський начіональний університет імені I.I. Мечникова, \\ факультет міжнародних відносин, політологї та соиіальних наук, \\ кафедра міжнародних відносин \\ вул. Дворянська, 2, 65082, м. Одеса, Украӥна
}

Згадані тези мають на меті показати базові засади європейського законодавства, що регулюють міграційні процеси, навести приклади невдалої інтеграції чеченських мігрантів в європейське суспільство на зламі двох епох та досить успішної черкеської політичної та культурної інтеграції в Йорданії протягом двох сторіч, проводячи паралель між двох етнічних груп Кавказу, що були змушені залишити свої рідні місця в різні періоди історії.

Імміграція - це процес, завдяки якому індивідууми стають постійними резидентами або громадянами нової країни. 3 історичної точки зору, досвід імміграції тривалий та всілякий і здебільшого вважається корисним для соціального, економічного та культурного розвитку суспільств. Останнім часом міграційні процесі на Близькому Сході та у Північній Африці становлять серйоз- 
ний глобальний виклик. У 2015 та 2016 рр. Європейський Союз (СС) був захоплений безпрецедентним напливом біженців та мігрантів. Свропа ані в моральному, ані в правовому відношенні не була готова протидіяти такому розвитку подій. Європейське правове поле базується головним чином на Лісабонському договорі (упродовж Римського та Маастрихтського договорів) як конституційної складової частини, а також на Шенгенській угоді 26 європейських країн і Дублінському регламенті як операційній складовій частині. Дублінський регламент (Регуляторні правила № 604/2013, іноді Дублінський регламент III) - це закон СС, який визначає: «Яка держава-член СС відповідає за вивчення заяви на притулок, що було подане особою, яка намагається отримати міжнародний захист усередині Європейського Союзу згідно з Женевською конвенцією та Кваліфікаційною директивою ЄС (2005/36/ЕС Європейського парламенту та Ради від 7 вересня 2005 р., щодо «визначення професійних кваліфікацій»). Крім кризи з сірійськими біженцями, був невдалий попередній приклад чеченської меншини, яка намагалась інтегруватись в європейське суспільство внаслідок чеченсько-російських війн на Кавказі. Їх інтеграції сильно заважали певні традиції та особливості чеченської самосвідомості, тобто першочерговості традиційного права та звичаїв життя за «законами батьків», а не держави, погляди на роль жінки, правила кровної помсти, колективна відповідальність та замкненість чеченської діаспори.

До речі, історії відомі деякі успішні приклади інтеграції етнічних меншин у нові суспільства внаслідок втечі від військових конфліктів та загрози геноциду. Черкеська етнічна група становить лише $1 \%$ від загальної кількості населення, але цей відсоток займає впливову політичну та культурну нішу. Стисле історичне посилання на попередній приплив біженців із Кавказу та їхнє поселення у Транс-Йорданії дає змогу виявити підхід, за допомогою якого черкеси досягли свого статусу в йорданському суспільстві та змогли втримати його. Вірність Хашимітської монархії явила собою ключовий фактор, який допоміг черкесам утриматись на високій політичній та соціальній позиції йорданського істеблішменту. Протягом двох сторіч військові спроможності та землеробський досвід черкеської меншини були перетворені та замінені на унікальну культурну спадщину та пам'ятні традиції, а також успішну діяльність у гуманітарній та політичній галузях. Нещодавні соціальні опитування йорданських черкесів виявили значне зменшення інтересу до репатріації на історичну батьківщину та відкрили неприємні реалі сьогоднішнього перебування у цій частині Кавказького регіону.

Ключові слова: міграційні процесі, інтеграція в суспільство, геноцид, вірність монархії, культурна спадщина, соціальні опитування, репатріація. 